\title{
François Péron and the Tasmanians: an unrequited romance
}

\section{Shino Konishi}

François Péron was my first. A slight man with a sickly aspect, blind in one eye and possessing a long patrician nose that gave him an imperious air, ${ }^{1}$ he had a tendency to be self-indulgent, was intensely political in his relationships, and was not averse to machination against anyone he developed a dislike for. He could easily tell the odd lie or bend the truth if he saw any benefit to himself in it. He certainly could not be accused of mincing his words. His dedication to self-justification and self-aggrandising was exasperating to say the least.

I first encountered Péron when I was an undergraduate history student. I found him repellent; almost everything he said was disagreeable. Initially I was only interested in refuting him, dissecting his words and proving that he was an ignorant egomaniac. It was what he said about indigenous people and how he perceived women that offended me. He could be callously clinical in his descriptions. He never refrained from running his cold eye over the body of a black man or woman, focussing on any physical quality he saw as lacking, aberrant, or simply unattractive. At times, he even seemed ridiculous. He lacked self-awareness and humility, so never missed an opportunity to present himself as a hero, a role that rested precariously on his slender frame.

Encountering others who felt the same way I did, it seemed that his way with words and his negative appraisals provoked strong reactions. ${ }^{2} \mathrm{He}$ is indeed a treasure trove of objectionable quotations. Yet, over the years I have begun to look beyond the snatches of description that spark such ire, humoured his ludicrous self-aggrandising, and slowly began to change my opinion of Monsieur Péron. When once I just dismissed him, now I try to engage with him. Without realising it I have developed a relationship with him, and like all romances it is turbulent. At times he appals me and I detest him. Then at other times, I affectionately imagine I see through his pompous façade, and see how he truly is. I guess I have cast myself in the role of tragic heroine, and want to redeem my man.

François Péron significantly changed my life. He was the first to make me want to become an historian. He was my first primary source - his writings, the first object of my study. While I have since developed relationships with others, he is still my first, and as such the most significant. I have journeyed to the other side of the world to see his handwritten letters and journals, to study the marginalia he wrote on drawings and texts, to touch the same paper on which 
he spent the last years of his short life writing, to feel whether he left any hidden remnant of himself imprinted on the surface. I also wanted to walk through the town from which he departed on his epic voyage; the town whose people he imagined had affectionately wished 'Ah, may you ... return once more to your country, and the gratitude of your fellow citizens! ${ }^{3}$ as he set sail for my side of the world. I have done all this in order to understand him better; to grasp what it was exactly that made him say those terrible things.

In 1800 , at the tender age of 25 , Péron was the last to join the expedition to the Great South Land. This was a scientific expedition devised by the veteran seadog, Post-Captain Nicolas Baudin, a voyage to the Southern Ocean and Terra Australis, to discover the natural history of this still incompletely charted territory. This expedition would eventually be co-opted by the newly formed Société des Observateur de l'Homme and intrigue none other than the future emperor Napoleon Bonaparte. The expedition was to transcend Baudin's humble amateur naturalist fantasies. However, I am jumping ahead, for how are you to know the significance of these things? I must return to Péron's life prior to the expedition so we can discern how he became that self-confessed 'irresponsible, scatter-brained, argumentative, indiscreet', opinionated, and alienating man, 'incapable of ever giving way for any reason of expediency'. 4

François was not born into a wealthy family, and his father died at an early age. So he was guided on the usual trajectory of an intellectually curious, eighteenth-century French man from the lower orders: he was encouraged to join the seminary. In the course of one of Napoleon's numerous campaigns he was forced to enlist, and became a prisoner of war at the age of 19. After his release he moved to Paris, and under the patronage of Master Petitjean, he enrolled in a medical degree, becoming a student of the esteemed men of science, and members of the Société, Antoine-Laurent de Jussieu and Georges Cuvier. ${ }^{5}$ Upon hearing of the expedition to Terra Australis, Péron abandoned his studies and immediately entreated his mentors to recommend him to the expedition. He was promptly assigned the post of zoologist. More importantly, he was also to serve as the expedition's anthropologist, a science still in its infancy. An artefact of its recent inception was the disparity between the two anthropological treatises that served as Péron's guidelines. Georges Cuvier's was inspired by the nascent nineteenth-century science of comparative anatomy, while Joseph-Marie DeGérando's Instructions were more commensurate with the eighteenth-century philosophical approach of Jean-Jacques Rousseau. ${ }^{6}$ Péron's own ethnography precariously straddles both approaches, revealing his inexperience and naïvety. 


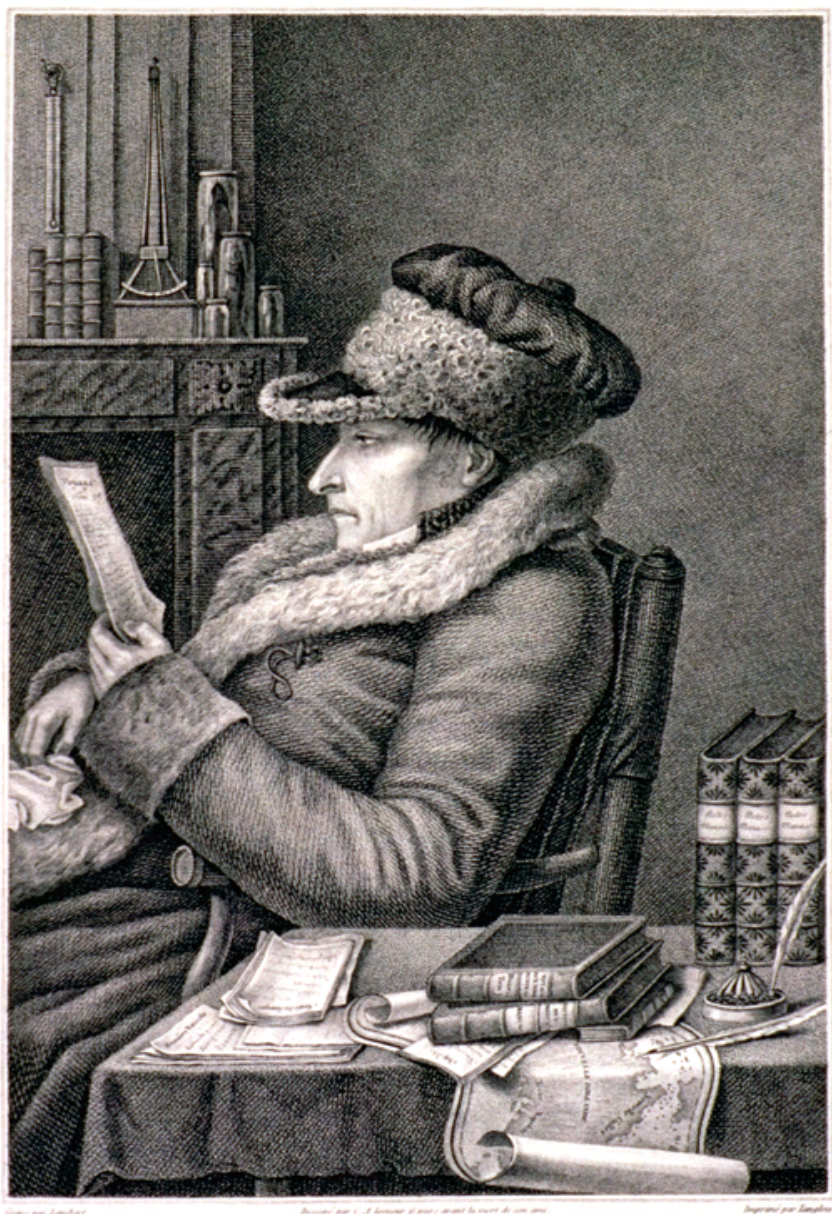

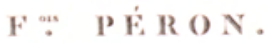

Figure 1.1: Fois. [i.e. Francois] Peron, nd, engraving by Lambert designed by Lesueur, Charles Alexandre, 1778-1846, Allport Library and Museum of Fine Arts, Tasmania

I had not anticipated arriving at Rousseau so early in this story. In order to best describe his significance, I need to jump ahead from Péron joining Baudin's expedition, skipping over the departure of the Geographe and the Naturaliste from Le Havre on the 19 October 1800 amid the fanfare and delight of the local citizens. ${ }^{7}$ I also need to skip past the ships' stop at the île de France (Mauritius) where they lost a significant proportion of their crew, disaffected by the slow trip and scant provisions for which Post-Captain Baudin was apportioned most 
of the blame. ${ }^{8}$ I want to pass over the brief visits the Geographe and the Naturaliste made to Western Australia including their first encounters with Aboriginal people, and even skip their longer sojourns in Tasmania and Port Jackson. ${ }^{9}$ In fact I want to skip over all of the events on the journey that changed him. Instead, I want to introduce you to Péron about halfway through the expedition, just after his departure from Port Jackson on 18 November 1802, when as we will see he had already become a disappointed man. ${ }^{10}$

It is at this stage of the journey that Péron chose to conclude the first volume of his journal. Although he and Louis de Freycinet are the joint authors of the four volume journal of the expedition, Voyage of Discovery to the Southern Hemisphere, Péron wrote volume one by himself. At this stage of the voyage the ships were about to return to France, by way of the southern coast of Western Australia. The last chapter describes the results of his dubious experiment intended to compare the physical strength of indigenous men with that of European men, using a newly invented mechanical contraption known as Regnier's dynamometer. $^{11}$

It is within this apparently objective and empirical context that Péron launches into a typically derogatory and bitter description of the Tasmanian people. He begins his attack with a minutely detailed disquisition on their bodies, ${ }^{12}$ easing into his subject matter by stating that the Tasmanians' height is similar to that of Europeans. The head attracts Péron's attention because he thinks it 'uncommonly large', and oddly proportioned, being much longer than it is wide. His eye sweeping down the length of the body, François turns to the torso, and appears to take a more positive tack. The Tasmanian men's shoulders are broad, their loins 'well formed', and their buttocks 'sizeable', 13 though due to his economic phrasing it is difficult to say whether he appreciates their form or not.

However, as his eye descends to the legs Péron's aim becomes clear. He has elaborated on the muscular stockiness of their torso only to heighten the feebleness of the Tasmanians' extremities. His eye can discern 'scarcely any muscle'. Even Péron's syntax highlights their scrawniness, for he ends the sentence by describing the way their abdomens project over their spindly legs like an inflated 'balloon'. This vignette on the Tasmanians' bodies is classic ethnography à la Péron, a dish that has often been tasted. ${ }^{14}$

But it is not just their bodies that come under attack - he also dismisses Tasmanian society, polity, abode, arts and diet. Péron's entire description is damning. It inexorably and predictably leads to his pronouncement that the inhabitant of these regions unites all the characters of man in an unsocial state, and is, in every sense of the word, the child of nature'. ${ }^{15}$ This is a familiar sentiment to any student of Aboriginal history. And it is here, with his self-indulgent use of italics, that the reason for Péron's ire reveals itself. He is 
striking out against those 'vain sophists' who 'attribute to savages all the sources of happiness and every principle of virtue'. ${ }^{16}$

Now Rousseau can enter the story. As a student François had been influenced by that eminent philosopher. He was seduced by the fantasy of the Noble Savage, a child of nature, not only more virtuous than civilised man, but physically superior in both form and function. So at first glance Péron's vitriolic attack on the body of the Tasmanians appears to be fuelled by the bitter disappointment of a former acolyte; by the realisation that his deeply held faith was a mere phantasm.

My first sympathetic understanding for François came from believing that his disillusionment with 'J.J' ${ }^{\prime 7}$ (as he intimately referred to Rousseau) was heartfelt and emotional, perhaps nourished by the passion of losing his father. His filial tragedy led me to suspect that he could not take the disappointment of a fallen paternal figure such as Rousseau lightly. I believed that the tragic romance was between Rousseau the mentor and Péron the succeeding disciple. Naturally, I concluded that the Tasmanians were merely innocent unfortunates caught in the crossfire, purely a means to Péron's end of proving that Rousseau was a charlatan philosophe. The idea that the Tasmanians themselves played almost no role in shaping these derogatory European attitudes was compelling, and seemed to be a view commonly held by other writers. ${ }^{18}$

However, re-reading Péron again and again, I have come to question this belief, for Péron was not always damning in his appraisals of the Tasmanians. It seems that his vitriolic fire was not sparked by Rousseau alone, but also fanned by the Tasmanians: not by their debasement and corporeal deviancy as Péron implies, but rather by their cool indifference to him, their reluctance to play the foil to his heroic self-imaginings. So I have come to the conclusion that François' unrequited romance was not with Rousseau at all, but instead with the Tasmanians.

I will now return to François, as he was on 13 January 1802: a prodigy in the science of natural history, idealistic, expectant, and full of vim and vigour. His enthusiasm should no doubt partly be attributed to the relief of finally catching sight of Tasmania after an arduous 61-day journey from Timor marked by dysentery, death and despair. It was on this fateful day that he first encountered the Tasmanians.

François beheld an Arcadian vision when he saw the Tasmanian coast. Despite the brisk temperatures he stood on the deck of the Geographe transfixed by the sight of the 'lofty mountains', the inland plains which rose 'in amphitheatres' over the whole island and the 'immense forests' ${ }^{19}$ He listened to the calls of the seabirds that circled the ships and the dolphins' splashes as they danced in 
the Geographe's wake. All the sights and sounds contributed to François' solemn feeling that he had 'touched the extreme boundary of the southern world'. ${ }^{20}$

His admiration of the landscape grew as the ships sailed into the d'Entrecasteaux Channel in search of fresh water. The lush green of the vegetation and prodigious mountains, combined with the beautiful plumes of the local parrots and majestic swans led François to declare that it was the 'most picturesque and pleasant' place they had seen during their long voyage. ${ }^{21}$ It was in this halcyon environment that Péron first glimpsed the Tasmanians.

As the ships approached the shore two men fleetingly appeared on the beach, disappearing as the ships neared. Then, shortly after the French disembarked, another two men appeared. The braver of the two immediately bounded down the rise to greet them. This young man captivated Péron with his athleticism for he 'seemed rather to spring from the top of the rock than to descend from it'. $^{22}$ His physicality made him appear 'strong' and the only defect he appeared to have was an apparent looseness to his joints. François scanned the Tasmanian's face, and upon seeing that his eyes were 'lively and expressive', concluded that his 'physiognomy had nothing fierce or austere' about it. ${ }^{23}$

This figure bewitched François. He was his Noble Savage, a man of impressive physical strength and dexterity with an open and guileless demeanour. Péron's compatriot Freycinet immediately embraced the man and François followed suit. It was in this fleeting caress that Péron got his first inkling that his appreciation was not reciprocated. The aloof Tasmanian seemed to receive the French embrace with an 'air of indifference'. But in the fever of excitement from finally beholding this fabled noble savage, Péron overlooked this minor rebuff. Instead, he interpreted this distance as a sign that physical displays of affection had little meaning to the man, a theory he would later apply to all Tasmanians. ${ }^{24}$ But for the time being, Péron was enchanted by the man's insatiable curiosity.

Immediately after their embrace, or possibly even during, the Tasmanian ran his hands over the Frenchmen's clothes, marvelling at their white skin and their layers of attire. Opening their jackets and lifting their shirts, perhaps even rolling up their sleeves and tugging at their waistbands, he inspected their skin, punctuating his fervid manoeuvring with 'loud exclamations of surprise' and stamping a rapid little tattoo with his feet. ${ }^{25}$ The French boat then caught his eye, and he rushed over to inspect it with the same zeal. Ignoring the men still seated aboard he jumped in and immediately began running his hands along the boards, the mast and so forth.

He was distracted momentarily by a bottle of arrack given to him by one of the bemused sailors. Holding the bottle in the sun he slowly turned it, catching the rays of light that glinted off its surface, but then promptly threw it overboard, returning his attentions to the boat. ${ }^{26}$ The flurry of activity as one of the 'vexed' 
sailors splashed into the water to rescue the valuable liquor did not distract the Tasmanian who by then was endeavouring to push the boat off and master the art of sailing for himself. François was charmed by the man's display of energetic inquisitiveness, and impressed by his deductive reasoning, for he would later write with patronising warmth that they were 'the most striking demonstrations of attention and reflection which we had ever seen among savage nations' ${ }^{27}$

While this scene was being played out in the water, Péron and Freycinet wandered further ashore to meet the second Tasmanian in a somewhat less frantic exchange. This man's salt-and-pepper hair and beard suggested that he was more than 50 years old. While obviously anxious and frightened by the strangers' sudden appearance, he still managed to give an impression of 'kindness and candour' ${ }^{28}$ After the obligatory scrutinising of their white skin and dishevelling of their clothes, he beckoned two women to join them on the beach.

Taking a moment to deliberate, the women approached, though this time the elder of the two took the lead. Her complete nakedness revealed that the skin of her belly was a topography of 'furrows' and ridges, a telltale sign for Péron that she had mothered many children. ${ }^{29}$ The younger woman nursed a baby girl, giving Péron an excuse to linger over his description of the shape and fullness of her bosom. But when he lifted his gaze to her face he was taken aback by her expression as she openly returned his stare. Unlike the 'kind and friendly' countenance of the older couple, this young woman had 'fire' burning in her eyes. $^{30}$ Yet, as her eyes flitted back to her baby they changed, becoming warm with affection as she fondled and cared for it in a display of 'maternal love' that François could only assume was a peculiarity of women the world over. Again, Péron overlooked her momentary flintiness in his enchantment of their presence.

After this meeting Péron's compatriots wished to move on to begin their scientific transactions, but François opted to stay with the two women and the Tasmanian patriarch in an endeavour to 'collect some words of their idiom'. ${ }^{31}$ Meanwhile the young man continued his active engagement with the sailors, gathering wood and lighting a fire upon realising the Frenchmen's desire to warm themselves. As both parties converged at the fire François had another opportunity to delight in the innocence of these children of nature.

Suddenly the young woman let out a scream, which 'alarmed' everybody. Upon realising the cause of her distress the French were filled with mirth, laughing heartily at her childlike mistake. Having mistaken a sailor's gloves for a hand, she feared that this alien man could simply detach it 'at pleasure'. ${ }^{32}$ It is this first stage of the romance, during the attraction that François feels at first sight of the Tasmanians, that the ill-fated bottle of arrack again re-enters the story.

During this initial flirtation, Péron's boorish seduction routine of condescendingly laughing at the Tasmanian woman soon causes the romance to stall. Under the 
cover of this distraction, the elderly patriarch takes the opportunity to take the same bottle of arrack that had been given his son and carry it off towards his camp. ${ }^{33}$ The loss of such a valuable resource, comprising 'a great part' of their 'stock', necessitates the sailors' vigorous repossession of the bottle, but the erratic behaviour of the Frenchmen concerning this gift incites much discontent in the old man, and ignoring the French gestures of appeasement and requests to stay, the Tasmanian family immediately take their leave, and temporarily exit the story.

Despite this hiccup in the budding relationship, François was still confident in his ability to worm his way into the noble savages' affections, for tomorrow is another day, so he replaces his anthropologist hat with his zoologist one for a spot of shell collecting.

Now I would like to open on a new scene. Later that afternoon a party of Frenchmen, hoping to alleviate their disappointment at not finding fresh water with a collecting success, ventured further along the shore and discovered a Tasmanian hut and canoes. ${ }^{34}$ After inspecting them and evaluating their apparent lack of sophistication and workmanship, they again met the Tasmanian family whose number had since swelled to nine.

The family rushed towards their visitors with cries of delight and joy, the earlier altercation forgotten. ${ }^{35}$ They took the sailors back to their hut where the hospitable family prepared a simple meal of broiled shellfish, which the Frenchmen found to be 'succulent and well-flavoured'. In reciprocation for their fine meal the guests decided to regale the Tasmanians with a spirited rendition of La Marseillaise, ${ }^{36}$ though Péron insisted that its true anthropological purpose was to 'see what effect our singing would have on our audience'. ${ }^{37}$ The Tasmanians did not appear surprised by the sudden rendition, though responded to the music with 'diverse contortions' and 'odd gestures'; the French could barely contain their laughter. But the Tasmanians' immediate 'exclamations of admiration' at the conclusion of the stirring anthem led Péron to infer that their strange reactions were positive. Encouraged by this reaction Péron decided to entertain them with another song. 38

Almost imagining the lights dimming and a change in tempo, François advanced his romantic dalliance one step, from attraction to seduction. The French began by crooning some of their 'tender airs'. Even though the Tasmanians appeared to 'comprehend the sense of these' romantic ballads, they seemed strangely unaffected. ${ }^{39}$ After what I can only imagine was an uncomfortable period of silence, a new character entered, the Tasmanian belle Ouré-Ouré, who broke the awkward atmosphere as she introduced the next scene.

Ouré-Ouré was about 16 or 17 years of age, and thought to be the younger sister of either the energetic young man or his flinty wife. François freely admitted 
that she attracted their keenest attention. Her complete nudity and 'delicate' form could not be ignored, but François, in a moment of chivalry, refrained from clinically describing her body, and only conceded that she seemed beguilingly unaware that there could be anything indecent or immodest about her 'absolute nudity' ${ }^{40}$ He perceived her glances toward them to be 'affectionate and expressive', though acknowledged that Freycinet had drawn more of her attention. François and the Tasmanians were now advancing to the next stage of the romance, the mutual flirtation.

For François, Ouré-Ouré was a natural coquette: delivering affectionate glances and winning smiles, and possessing a fine figure. Yet, when she took a more active role in the flirtation Péron's reaction became ambivalent, perhaps belying either the limited experiences that almost saw him join the seminary, or his unmediated preference for white skin. ${ }^{41}$ In short, her coy preening was simultaneously enticing and disturbing. 'Taking some burnt charcoal in her hands, she crushed it so as to reduce it to a fine powder' then daubed it all over her face, expressing a confident and satisfied attitude towards her beauty regimen. ${ }^{42}$ The Frenchmen were flattered by her attentions and amused to discover that 'fondness for adornment ... prevails in the hearts' of all women, but Péron was also distressed by how 'frightfully black' it made her. ${ }^{43}$ Yet in a romantic gesture François accepted this new look of Ouré-Ouré's and later seized the opportunity to try to usurp Freycinet in her affections. Noticing that she owned a bag made of rushes he thought to himself 'as this girl had also shewn me some marks of regard' I will venture 'to ask her for this little trifle'. ${ }^{44}$ At his behest she immediately gave him the bag, and moreover accompanied it with 'an obliging smile' and 'some tender expressions' that he lamented not being able to understand. In response to this flirtation François inundated her with presents, including a handkerchief, a hatchet and a hammer, despite having been ordered by his captain to be sparing with his gifts. ${ }^{45}$

François was enamoured not only with the Tasmanians' hospitality and camaraderie, or Ouré-Ouré's affections, but also with the playful mischievousness of the children, and the ease with which he felt he had conversed with the Tasmanians despite their not being able to understand each other. Upon bidding their adieus the French were accompanied back to their boat by the Tasmanians who met the other French sailors, most of whom also noticed Ouré-Ouré's considerable attractions and festooned her with even more gifts. The Tasmanians' seeming commitment to the budding relationship was evident in their reluctance to allow the Frenchmen to leave. ${ }^{46}$

This day would be François' most romantic with the Tasmanians, full of laughter and affection. He was impressed not only by how the family had embraced their visitors but also the warmth they had shown one another. Later he would reflect that on that day he 'saw realized with inexpressible pleasure, those charming 
descriptions of the happiness and simplicity of a state of nature, of which I had so often read, and enjoyed in idea' ${ }^{47}$ Yet only two days later, on 15 January, Péron would begin to rethink this evaluation.

On that fateful day Péron was completely oblivious to how events would play out. In fact he was not even thinking of the Tasmanians, but instead was busy charting the marshy Port of Swans in a small boat, marvelling at the local countryside and wildlife. The party of naturalists discovered a river, which they named after the celebrated hydrographer Fleurieu, and Péron decided that a European colony should be established there, as the river would supply the settlement with water all year round. ${ }^{48}$

Meanwhile, hostilities between the French and indigenes flared over on Bruny Island. That day a small party of the French had ventured out on a fishing expedition. Shortly after landing they encountered a group of Tasmanians. Péron later learned that a burly midshipman by the name of Jean Maurouard, anticipating the study Péron would later conduct with his dynamometer, had also decided to test the strength of the infamously physically adept noble savages. $^{49}$

Upon meeting the Tasmanians the French again presented them with gifts, and to all intents and purposes the 'natives' seemed friendly, inducing Maurouard to feel at liberty to try something new. Selecting the Tasmanian who 'appeared to be the most robust', he indicated his desire to engage in a little roughhousing. Planting his feet firmly in the sand, the Frenchman grabbed the Tasmanian's wrist and gestured that both should 'pull as hard as possible'. ${ }^{50}$ Assuming that his gestures were fully comprehended the midshipman engaged in numerous feats of strength, repeatedly toppling or throwing his opponent into the sand. Mighty Maurouard won out every single time, but as the game was played amid much laughter and frivolity he did not anticipate the Tasmanian reaction.

Tiring of wrestling and collecting fish, the Frenchmen decided to withdraw to the ship, so again said their goodbyes and presented more gifts. His back turned to the Tasmanians as he pushed the boat out into the water. Maurouard was struck in the shoulder with a spear. ${ }^{51}$ The point grazed the midshipman's shoulder blade and lodged in the flesh between his neck and shoulder. The Frenchmen immediately sprang into action. Sub-lieutenant St. Cricq drew his pistol, and with the unstoppable Maurouard charged back up the rise to find the attacker. Baudin reports in his journal that they then noticed seven or eight armed men, who did not react upon spying the pursuing Frenchmen. The Frenchmen, seemingly struck by their peculiarly uninterested demeanour, decided that it was most prudent to return to the ship, and retreated back down the rise without any further incident. ${ }^{52}$ But Péron reports the story slightly differently. 
When Péron heard news of this attack a few days later on his return from the Port of Swans he was filled with horror. How could those noble savages whose company he had so thoroughly enjoyed only days earlier have behaved so barbarically? But then perhaps he recalled those brief incidents during his first day when their response had been cool or indifferent, not to mention their attempt to steal the arrack. Perhaps those minor rebuffs by the Tasmanian men preyed on him. He certainly remembered the hostile attacks that they had suffered on the west coast of New Holland. Possibly the Tasmanian men were not as different from their mainland neighbours as he first thought. Péron judged this attack to be a 'perfidious and cowardly' display of brutality. ${ }^{53} \mathrm{He}$ immediately assumed that it was a vindictive response to their resounding defeat at the hands of Maurouard.

It never occurred to him that the Tasmanians might have been demonstrating their own indigenous game of skill, the art of spear dodging, or that the Tasmanians might have tired of their presence and wanted the interlopers to leave. In fact Péron cannot even entertain the notion that the Tasmanians have any motivation other than an inherent 'destructive instinct', 54 because to him they are little more than a cipher for his fanciful projections. His penchant for melodrama, which becomes more and more pronounced over the course of his journey, reveals itself in his retailing of this incident. According to his narrative the French immediately gave pursuit, and he claims they would have 'punished them as they deserved' had the cowards not already 'escaped among the rocks, or hid themselves among the brambles'. ${ }^{55}$ This would not be the only time that Péron allowed his fantasies to obscure the truth.

After a reprieve of only a few days, the French had another encounter with the Tasmanian men that played out in a similar fashion, again resulting in 'violent aggression' ${ }^{56}$ For a second time Péron was absent so missed out on the action, but at his request the botanist Leschenault wrote him a report, so he had all of the important details. That is to say, the report described the violent events, mentioning neither how the Tasmanians were encountered nor what their attitude had been, because after the spearing of Maurouard the French could only see the Tasmanian men's actions as inexplicably and instinctively violent.

This day began with a party of Frenchmen, led by Jean Félix Emmanuel Hamelin, captain of the Naturaliste, and including the artist Nicolas-Martin Petit, setting out in order to make some progress on their ethnographic research. After meeting a group of Tasmanians Petit drew some portraits of the men as they sat in repose smiling and talking. Despite their relaxed demeanour Petit was soon to realise that they were not merely passive anthropological subjects, for once Petit had finished the portraits, one of his subjects suddenly grabbed hold of the drawing. In the ensuing struggle of wills Petit steadfastly held on to his work, forcing the Tasmanian to relinquish his hold and up the ante by seizing and brandishing 'a 
log of wood' at Petit. Thanks to the spearing of Maurouard the French were on guard against potential attacks, so the rest of the party immediately rallied to the artist's side. The increased support induced the man to surrender his claim to his portrait, though not his indignation. Despite French attempts to placate the Tasmanians with another round of gifts, they were sent running back to their ships with a volley of rocks. ${ }^{57}$

The botanist Jean-Baptiste Louis Claude Leschenault reported this second attack to Péron, who included it in the official journal of the voyage. Leschenault's report contained the critique of Jean-Jacques Rousseau which would come significantly to influence Péron: 'I am astonished, ... to hear sensible people aver, that men in a state of nature are not wicked. ${ }^{58}$ He goes on to say it is preposterous to believe that the natives never played the role of aggressor. Two attacks were evidently enough for Leschenault to reject the claim that the Tasmanians were noble savages. François on the other hand, with lingering memories of Ouré-Ouré, still had a soft spot for the women.

On the last day of the month, after almost two weeks with little contact, Péron came across a group of Tasmanians. Following Leschenault's advice to the letter he turned back 'without hesitating a moment' ${ }^{59}$ Beating a hasty retreat along the shoreline he happened to meet sub-lieutenant François Antoine Boniface Heirisson. Bolstered by this extra support, he decided to return to where he had seen the 'natives'. Realising that they had no chance of catching the Tasmanians if they chose to avoid them, Péron and Heirisson signalled their good intentions by calling out, holding up their presents so they could be seen, and 'waving their handkerchiefs' ${ }^{60}$ The group eventually submitted to these entreaties and stopped, allowing Péron and Heirisson to catch up. It was as he approached that François realised that 'they were women, and that there was not a single male among the party'. ${ }^{61}$ This realisation instantly lifted his spirits. Unfortunately these women were not to live up to Péron's fantasies, for they were hardly shy and malleable coquettes.

From the outset the women were in control. It was the women who allowed the Frenchmen to draw near, the women who instructed them to sit, and the women who made them disarm. ${ }^{62}$ The Frenchmen not only had to submit to the women's instructions but also had to tolerate their interrogations and mockery. Péron thought that they seemed 'often to criticise our appearance', and laughed 'heartily at our expense' ${ }^{63}$ When the surgeon Jérôme Bellefin attempted to repeat their earlier success with the Tasmanians by singing to them, the women again seemed to appreciate it, but one, who they later learned was called Arra-Maida, ${ }^{64}$ mimicked his 'action and the tone of his voice', and then began to sing and dance herself. ${ }^{65}$ Her singing had such an unfamiliar melody that Péron thought it difficult to 'give any idea of music' and her dancing plainly shocked Péron: her contortions and 'attitude' bordered on 'indecent', forcing him to primly note 
that these savage people were still absolute 'strangers to all the delicacy of sentiment and conduct' that was a natural 'consequence of complete civilization' ${ }^{66}$

Péron's earlier ambivalence regarding Ouré-Ouré and her seduction routine was only exacerbated when he was confronted by these brazen paramours. Having been tantalised by Ouré-Ouré and entranced by her demure flirtations which allowed him to play the role of chivalrous seducer, he was clearly taken aback at being forced into the role of blushing coquette himself. However, his surprise at this inversion of roles paled in comparison to the women's attempt to transform the Frenchmen's appearance. Once Arra-Maida had finished her performance she approached Péron. From her rush bag, similar to Ouré-Ouré's, she took some charcoal and began crushing it between her hands just as Ouré-Ouré had done, but instead of powdering her own face she begun applying it to Péron's. After finishing his face Arra-Maida then blackened Heirisson's. Even though both men 'submitted to this obliging piece of caprice', and Péron even recognised that the Tasmanians might have the same disdain for white skin that Europeans had for black, this meeting with the women cooled Péron's ardour for the Tasmanians. ${ }^{67}$

In contrast to his chivalrously discreet account of the delectable Ouré-Ouré, Péron openly stared at these women, and then described their bodies in clinical and derogatory detail, picking out any flaw, no matter how minor. His description is loaded with negative adjectives, and a sense of their utter degradation is suggested by his syntax, which scans their bodies from top to bottom, cataloguing an exhaustive account of imperfections. ${ }^{68} \mathrm{He}$ concluded his general assessment of the women by stating that 'in a word, all the particulars of their natural constitution were in the highest degree disgusting'. ${ }^{69}$ Péron acknowledged that the young girls possessed an 'agreeable form and pleasant features' but unfortunately their 'nipples were rather too large and long'. ${ }^{70}$ It seems that for Péron signs of the women's transgressive behaviour and nature were now physically manifested in their bodies.

Even though Péron's opinion of the Tasmanian men and women had become jaded, he was not the one to end the romance. Despite his ambivalence regarding the attractiveness of the women Péron stayed with them as long as he could, playing the dupe to their 'many tricks' and 'drolleries' and enjoying a 'merry' time. As he followed them home from their fishing expedition musing on the unjust burdens imposed on savage women, he was suddenly roused from his reflections by one woman's 'loud cry of terror'. The women had just caught sight of the manned French boats. ${ }^{71}$ The realisation that there were more intruders waiting just off the shore ignited their fears, and all but one of the women fled towards the forest. The indomitably courageous Arra-Maida hectored her fleeing sisters and eventually convinced them to escort the party back to 
their boat. As they neared the shore Péron realised that the 'husbands' of these women had also converged where the boats were moored, but instead of being fearful they appeared to be filled with 'malevolence' and suppressed anger, which Péron assumed to be consequent to their 'inability to contend' with the superior Europeans. ${ }^{72}$ Yet the Tasmanians seemed to have decided that the best way to contend with the French trespassers was to spurn their advances by evading them and giving the Frenchmen an apparently unambiguous sign of their disdain.

On 3 February, only a few weeks after their first meeting, the French returned to Bruny Island. ${ }^{73}$ On seeing two women walking down the mountain to the sea, two of the French who had yet to encounter the Tasmanian women immediately ran towards them hoping for a closer look. When the women realised they were being pursued they sprinted off, disappearing before the men were able to catch them. Disappointed, the entire French party continued along the coast, and eventually spied a huge bonfire that appeared to have been burning since the night before. As they approached the pyre they realised that it was surrounded by 'almost all the presents' that the French had given to the Tasmanians. Like any jilted lover Péron was in denial. Instead of recognising that the Tasmanians were breaking up with him, he imagined that this bonfire and deliberate return of their gifts was just a manifestation of their 'puerile curiosity'. He deluded himself by thinking that 'these uninformed men threw away what no longer pleased or amused them', ${ }^{74}$ and refused to recognise that it was actually he and his compatriots who no longer pleased the Tasmanians.

Had this romance been a fiction rather than being based on historical events the story would have ended here, perhaps with Péron mourning the end of the affair, or moving on to look for another race of impossible noble savages. But the harsh and prosaic reality of the situation was that Péron and the French lingered, unwanted, in Tasmania for a few more weeks, having other meetings with the Tasmanians and making further attempts to study these children of nature. The French continued to try to draw their portraits, document their vocabularies, discern whether or not they indulged in 'kisses and tender caresses', and test their physical strength with their dynamometer. ${ }^{75}$ Their attentions were frequently rebuffed, and encounters usually ended in violent or aggressive altercations, with the French having to resort to drawing their weapons.

One particularly exciting encounter for Péron involved a dispute over his jacket. Having been offered many gifts, one of the Maria Island Tasmanians decided he wanted Péron's jacket and repeatedly asked for it. After being denied one too many times he grabbed his spear and threatened the Frenchman with it. Péron later wrote that he 'seemed to say, "Give it to me, or I will kill you"'. 76 This scene, in which Péron portrays himself as the quintessential cool, calm, and collected hero, continues with Péron laughing at the man and pretending it was 
all a joke. Suddenly, Péron grabbed hold of the spear end, and pushed it away from his face. Coolly, the hero then simply pointed at his handsome sidekick, First Class Seaman B.J. Rouget, who had his musket aimed at the aggressor, and 'added one single word of his own language (mata), death' ${ }^{77}$ The man immediately surrendered his claim to the jacket.

As I read over this scene again, I have to wonder if it really did play out in this way. Was Péron so calm in the face of death? Did the Tasmanians really have such a 'treacherous disposition'? ${ }^{78}$ Or was it yet another example of Péron's overactive imagination and self-aggrandising fantasies? Having read Péron numerous times I wonder if this scene isn't a bitter and desperate attempt to save face after being rebuffed and jilted by the Tasmanian noble savages.

So why did I develop some sympathy for François, this vindictive, 'irresponsible, scatter-brained, argumentative', and 'indiscreet' man? It was not because he lost his father at an early age, and not even because he was a prisoner of war held at three different compounds while still a teenager. My change of heart was because after years of reading him again and again, I recognised that he had been searching and longing for something that did not exist. He had adopted such a passionate faith in a singular idea that it bordered on religious zeal. $\mathrm{He}$ was desperate to find the perfect noble savage, a tabula rasa on which to project his fantasies of an ideal human society. When he finally found it on the temperate shores of Tasmania, he did not anticipate that things would play out the way they did. He never expected that his offerings and paternalistic guidance would be rejected, that the noble savages would refuse to do his bidding and be model subjects for his study, and that they would fail to behave as Rousseau had led him to believe. So he reacted with the vindictiveness of a rejected lover.

So you may ask again, why do I sympathise with Péron? The answer is simply because his quest mirrored my own. As an indigenous historian I have combed these first contact narratives for any accounts and revelations about pre-contact Aboriginal people in order to greater understand the heartbreaking experiences and momentous changes that colonisation wrought for indigenous Australians. Despite seeing myself as standing at the opposite end of a temporal and colonial abyss from François Péron and his eighteenth-century European counterparts, I now realise that we are in some instances uncomfortably aligned. For I, like François, have idealistic fantasies about Aboriginal society and have attempted to impose this romanticised vision on the historical record. In doing so I have come to realise that I have inadvertently glossed over the complexities and idiosyncrasies of pre-contact Aboriginal society, and that I have ignored the playful and amicable relations that were formed in those first moments of contact. I have been blind to the power that the indigenous people had in those early colonial encounters. Like Péron I made the mistake of misinterpreting and misjudging the agency of eighteenth-century Aboriginal people. I sympathise 
with François because unlike him I eventually recognised this, and now I can fall in love with the Tasmanians and other indigenous historical figures all over again.

\section{References}

Baudin, Nicolas 1974, The Journal of Post Captain Nicolas Baudin Commanderin-Chief of the Corvettes Géographe and Naturaliste, assigned by Order of the Government to a Voyage of Discovery, Christine Cornell (trans.), Libraries Board of South Australia, Adelaide.

Cuvier, Georges 1978, 'Note Instructive Sur Les Recherches A Faire Relativement Aux Différences Anatomiques Des Diverses Races D'Hommes' in Jean Copand and Jean Jamin (eds), Aux Origins de L'Anthropologie Française: Les Mémoires de la Société des Observateurs de l'Homme en l'an VIII, Le Sycomore, Paris: 171-176.

Degérando, Joseph-Marie 1969, The Observation of Savage Peoples, FCT Moore (trans.), University of California Press, Berkeley and Los Angeles.

Hughes, Miranda 1988, 'Tall Tales or True Stories? Baudin, Peron, and the Tasmanians, 1802', in Roy Macleod and Philip F Rehbock (eds), Nature in its Greatest Extent: Western Science in the Pacific, University of Hawaii Press, Honolulu: 65-86.

Jones, Rhys 1988, 'Images of Natural Man', in J Bonnemains, E Forsyth and B Smith (eds), Baudin in Australian Waters: The Artwork of the French Voyage of discovery to the Southern Lands 1800-1804, Oxford University Press, Melbourne: 35-64.

Laissus, Yves 1988, 'François Péron: A Biographical Note', in J Bonnemains, E Forsyth and B Smith (eds), Baudin in Australian Waters: The Artwork of the French Voyage of discovery to the Southern Lands 1800-1804, Oxford University Press, Melbourne: 31-34.

Lesueur, Charles-Alexandre, François Péron, William Henry Smith Memorial Library, Indiana Historical Society, Indianapolis.

O'Brien, Patty 1999, 'Divine Browns and the Mighty Whiteman: Exotic Primitivism and the Baudin Voyage to Tasmania in 1802', Journal of Australian Studies 63: 13-21.

Péron, François 1809, A Voyage of Discovery to the Southern Hemisphere, performed by Order of the Emperor Napoleon, During the Years 1801, 1802, 1803, and 1804, Richard Phillips, London.

Péron, François, n.d., 'Conférence addressee à 'Messieurs les professeurs', décrivant les aborigines et leur moeurs près de Port Jackson', Dossier 9: Expédition aux Terres Australes. Notes de Voyage, côtes Est et Sud de 
la Nouvelle Hollande (auteurs divers), No. 09032, Transcription de J Bonnemains, Collection Lesueur, Muséum d'histoire naturelle du Havre.

Plomley, NJB 1983, The Baudin Expedition and the Tasmanian Aborigines 1802, Blubber Head Press, Hobart.

Sankey, Margaret 2004, 'The Aborigines of Port Jackson, as seen by the Baudin Expedition', Australian Journal of French Studies 41(2): 117-125.

\section{ENDNOTES}

1 Charles-Alexandre Lesueur, François Péron.

2 Hughes 1988; O'Brien 1999.

3 Péron 1809: 16.

4 Deleuze, Voyage, 2, t. 1, 1824: 47, cited in Laissus 1988: 31.

5 Laissus 1988: 31-32.

6 Cuvier 1978; DeGérando 1969; Hughes 1988: 67-72.

7 Péron 1809: 16.

8 Péron 1809: 42-53.

9 Péron 1809: 71-4.

10 Péron 1809: 311-2.

11 Péron 1809: 222, 311-312; Sankey 2004: 118-119.

12 Péron 1809: 313.

13 Péron 1809: 313.

14 Plomley 1983: 161; Jones 1988: 46; Hughes 1988: 75.

15 Péron 1809: 313.

16 Péron 1809: 312.

17 Péron n.d.: Feuille A, verso, 'Conférence addressee à 'Messieurs les professeurs', décrivant les aborigines et leur moeurs près de Port Jackson', Dossier 9: Expédition aux Terres Australes. Notes de Voyage, côtes Est et Sud de la Nouvelle Hollande (auteurs divers), No. 09032, Transcription de J Bonnemains, Collection Lesueur, Muséum d'histoire naturelle du Havre.

18 O'Brien 1999: 21.

19 Péron 1809: 171.

20 Péron 1809: 171.

21 Péron 1809: 172.

22 Péron 1809: 173.

23 Péron 1809: 173.

24 Péron 1809: 173.

25 Péron 1809: 173-4.

26 Péron 1809: 173-4.

27 Péron 1809: 174.

28 Péron 1809: 174.

29 Péron 1809: 175.

30 Péron 1809: 175.

31 Péron 1809: 175.

32 Péron 1809: 176.

33 Péron 1809: 176.

34 Péron 1809: 177.

35 Péron 1809: 177.

36 Jones 1988: 45.

37 Péron 1809: 177. 


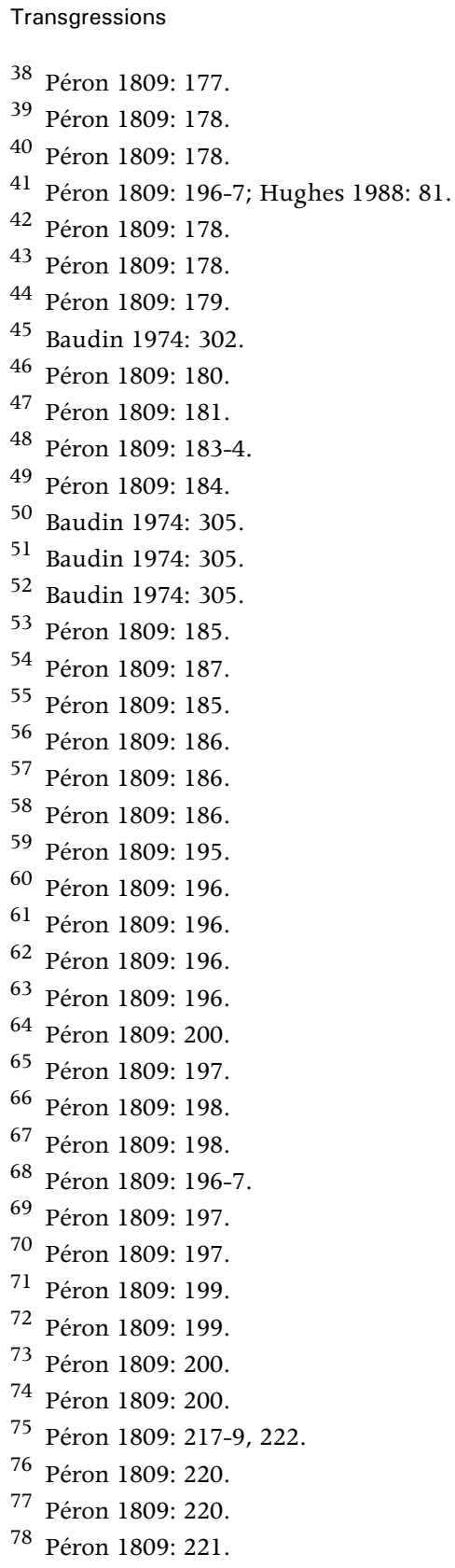

